AT-TAJDID: Jurnal Pendidikan Dan Pemikiran Islam

(p-ISSN: 2548-5784 |e-ISSN: 2549-2101)

Vol. (04) (02), (Desember) (2020), (Halaman)(168-177)

Doi: http://dx.doi.org/10.24127/att.v6521a1426

\title{
URGENSI PENELITIAN TINDAKAN KELAS DALAM MEMPERBAIKI PRAKSIS PEMBELAJARAN
}

\author{
Lailya Mufidah \\ Institut Agama Islam Negeri Jember \\ E-mail: lailyamfdh@gmail.com
}

\begin{abstract}
ABSTRAK
Penelitian Tindakan Kelas (PTK) merupakan bentuk penelitian tindakan yang dilakukan oleh guru secara sistematis reflektif untuk memperbaiki praktik pembelajaran di kelas dan meningkatkan kinerja guru sehingga menjadi guru yang profesional. Hasil dari penelitian yang telah dilakukan dapat dijadikan sebagai acuan untuk memperbaiki praktik pembelajaran menjadi lebih efektif. Tujuan dari penelitian ini yaitu untuk memperbaiki praksis pembelajaran. Adanya tindakantindakan tertentu yang dilakukan oleh peneliti (guru) untuk memperbaiki permasalahan pembelajaran menjadi karakteristik khas dari penelitian tindakan kelas. Adapun fokus kegiatan dalam pelaksanaan penelitian tindakan kelas antara lain; planning (perencanaan), acting (tindakan), observing (pengamatan), dan reflecting (refleksi). Setelah melakukan penelitian tindakan kelas, peneliti (guru) membuat laporan penelitian tindakan kelas. Hal yang perlu ditulis pada laporan penelitian tindakan kelas setidaknya memuat beberapa aspek yang berkaitan dengan keadaan kelas, hasil setiap siklus, dan analisis keseluruhan siklus. Karya ilmiah yang telah dibuat oleh peneliti (guru) bisa dipublikasikan melalui penerbitan ataupun presentasi.
\end{abstract}

Kata Kunci: Penelitian Tindakan Kelas; guru; kualitas pembelajaran.

\begin{abstract}
Classroom Action Research (CAR) is a form of action research carried out by teachers in a systematic, reflective manner to improve learning practices in the classroom and improve teacher performance so that they become professional teachers. The results of the research that has been done can be used as a reference to improve learning practices to be more effective. The main objective of classroom action research is to improve learning praxis. The existence of certain actions taken by researchers (teachers) to correct problems faced by teachers in classroom learning practices is a distinctive characteristic of classroom action research. The focus of activities in the implementation of classroom action research, among others; planning, acting, observing, and reflecting. After conducting classroom action research, the researcher (teacher) makes a classroom action research report. The things that need to be written in the classroom action research report contain at least several aspects related to the state of the class, the results of each cycle and the analysis of the entire cycle. Scientific works that have been made by researchers (teachers) can be published through publishing or presentations.
\end{abstract}

Copyright $\odot$ 2020, Universitas Muhammadiyah Metro| 168 
Keywords: Classroom Action Research; teacher; quality of learning

\section{A. PEndahuluan}

Permasalahan yang terjadi dalam proses pembelajaran kerap kali dialami oleh guru. Seperti menurunnya minat belajar siswa, hasil belajar siswa dan lain sebagainya. Jika permasalahan tersebut dibiarkan saja tanpa adanya perbaikan maka kualitas pendidikan akan semakin menurun dan tidak akan ada peningakatan. Salah satu upaya yang dapat dilakukan oleh guru untuk memperbaiki permasalahan dalam praktik pembelajaran dan meningkatkan kualitas pendidikan yaitu dengan melakukan penelitian tindakan kelas. Sehingga mutu pendidikan di sekolah akan semakin meningkat.

Pendidik sebagai tenaga profesional mempunyai peran, fungsi, dan kedudukan yang sangat penting dalam mencapai tujuan pendidikan. Sebagaimana yang termaktub dalam Undang-Undang Nomor 14 Tahun 2005 tentang Guru dan Dosen menyatakan bahwa pendidik adalah tenaga profesional dengan tugas utama mendidik, mengajar, membimbing, mengarahkan, melatih, menilai, dan mengevaluasi peserta didik pada pendidikan anak usia dini jalur pendidikan formal, pendidikan dasar, dan pendidikan menengah (Subyantoro, 2020). Agar profesionalitas pendidik selalu meningkat, maka pendidik seharusnya melakukan refleksi terhadap kinerjanya sendiri secara berkelanjutan dan memanfaatkan hasil refleksinya untuk meningkatkan keprofesiannya. Pentingnya penelitian tindakan kelas ternyata tidak diimbangi dengan pemahaman guru tentang penelitian tindakan kelas, seperti bagaimana proses pelaksanaannya dan apa saja manfaatnya untuk perbaikan pembelajaran (Ni'mah, 2017). Oleh karena itu, pendidik dituntut untuk memahami tentang penelitian tindakan kelas untuk memperbaiki pembelajaran dan mengembangkan profesionalitas guru.

\section{B. PEMBAHASAN}

\section{Pengertian Penelitian Tindakan Kelas}

Penelitian Tindakan Kelas (PTK) atau dalam literatur berbahasa Inggris disebut dengan istilah Classroom Action Research dikenalkan pertama kali oleh Kurt Lewin seorang psikologi sosial Amerika pada tahun 1946. Penelitian tindakan kelas sudah sejak lama berkembang pesat di negara-negara maju seperti Amerika, Inggris, dan Australia. Para ahli pendidikan di negara-negara tersebut memberikan perhatian yang begitu besar terhadap jenis penelitian ini (Subyantoro, 2020). Penyebab utamanya adalah karena penelitian tindakan kelas mampu memberikan solusi alternatif untuk memperbaiki proses pembelajaran dan meningkatkan profesionalisme guru (Sumini, 2010). Guru dapat melakukan penelitian tindakan kelas secara mandiri maupun kolaborasi dengan teman sejawat. Hasil dari penelitian yang telah dilakukan dapat dijadikan sebagai acuan untuk memperbaiki pembelajaran menjadi lebih efektif.

Menurut Stephen Kemmis penelitian tindakan kelas merupakan bentuk penelaahan melalui refleksi diri yang dilakukan oleh peserta kegiatan dalam situasi sosial (termasuk pendidikan) untuk memperbaiki kebenaran dan rasionalitas dari praktik sosial 
atau kependidikan yang mereka lakukan sendiri (Subyantoro, 2020).

Penelitian tindakan kelas sebagai upaya untuk mengidentifikasi suatu permasalahan di dalam kelas sekaligus memberi solusi untuk memecahkan masalah tersebut (Ni'mah, 2017). Menurut Wahidmurni dan Ali penelitian tindakan kelas diartikan sebagai upaya yang dilakukan oleh peneliti (guru) untuk memecahkan masalah dalam proses pembelajaran melalui penelitian (Susanti, 2015).

Sedangkan menurut Suyanto penelitian tindakan kelas adalah penelaahan penelitian yang bersifat reflektif dengan melakukan tindakan tertentu agar dapat memperbaiki dan/atau meningkatkan kualitas praktik pembelajaran di kelas secara profesional (Subyantoro, 2020). Seperti contoh, apabila dalam suatu kelas hasil belajar siswa menurun sehingga dapat menghambat pencapaian tujuan pembelajaran yang ditentukan, maka guru dapat melakukan penelitian tindakan kelas untuk memperbaiki permasalahan pembelajaran yang terjadi di kelas. Dalam melaksanaan penelitian guru dapat mencoba melakukan tindakan-tindakan yang bisa meningkatkan hasil belajar siswa, seperti menggunakan metode pembelajaran yang menyenangkan dan tidak monoton.

Dari beberapa definisi di atas, dapat disimpulkan bahwa penelitian tindakan kelas adalah bentuk penelitian tindakan yang dilakukan oleh guru secara sistematis reflektif untuk memperbaiki praktik pembelajaran dan meningkatkan kinerja guru sehingga menjadi guru yang profesional.

\section{Karakteristik Penelitian Tindakan}

\section{Kelas}

Setiap penelitian mempunyai karakteristik tersendiri yang berbeda antara satu dengan yang lain. Begitu pula dengan penelitian tindakan kelas yang mempunyai karakteristik khusus dan berbeda dengan penelitian lain. Karakteristik yang menonjol dari penelitian ini adalah dalam masalah yang hendak diteliti. Masalah yang hendak dipecahkan melalui penelitian ini harus berawal dari permasalahan yang dihadapi guru dalam proses pembelajaran sehari-hari di kelas. Karakteristik selanjutnya adalah bahwa penelitian tindakan kelas merupakan penelitian kolaboratif yang dalam pelaksanaannya melibatkan orang lain untuk bersama-sama menemukan dan memecahkan masalah yang terjadi dalam proses pembelajaran. Seorang pendidik dapat melakukan kolaborasi dengan dosen LPTK maupun dengan teman sejawat. Dengan demikian, pendidik akan banyak menerima masukan tentang bagaimana prosedur pelaksanaan penelitian tindakan kelas yang benar (Sumini, 2010).

Karakteristik berikutnya yaitu dapat dilihat dari kegiatan yang dilakukan dalam penelitian itu sendiri. Adanya tindakantindakan tertentu yang dilakukan oleh peneliti (guru) untuk memperbaiki permasalahan pembelajaran menjadi karakteristik khas dari penelitian tindakan kelas (Susilowati, 2018). Tanpa adanya tindakan, maka penelitian yang dilakukan hanya sekedar ingin mengetahui permasalahan yang terjadi, tanpa ingin memperbaiki permasalahan tersebut.

Menurut Richart Winter karakteristik penelitian tindakan kelas ada enam, antara Copyright (C) 2020, Universitas Muhammadiyah Metro| 170 
lain: pertama, kritik reflektif, yaitu upaya evaluasi terhadap hasil observasi yang telah dilakukan dan refleksi ini juga perlu adanya kritik untuk perubahan yang lebih baik. Kedua, kritik dialektis, dengan adanya kritik dialektif penelitian diharapkan bersedia melakukan kritik terhadap fenomena yang diteliti.

Ketiga, kolaboratif, maksudnya ialah dalam melakukan penelitian tindakan kelas perlu hadirnya kerja sama dengan pihakpihak lain seperti teman sejawat, peserta didik, dan lain sebagainya yang diharapkan dapat dijadikan sebagai sumber data dalam penelitian. Keempat, risiko, maksudnya ialah dengan adanya risiko peneliti diharapkan dan dituntut untuk berani mengambil risiko. Kelima, susunan jamak, maksudnya ialah penelitian tindakan kelas memiliki struktur jamak karena bersifat reflektif, dialektis, dan partisipasi atau kolaborasi. Keenam, internalisasi teori dan praktik, keduanya merupakan dua tahap yang saling bergantung dan berfungsi untuk mendukung transformasi (Subyantoro, 2020).

Dengan melaksanakan penelitian tindakan kelas, pendidik berupaya memperbaiki praksis pembelajaran di kelas agar menjadi lebih efektif. Akan tetapi, dalam pelaksanaannya tidak perlu mengorbankan proses pembelajaran hanya untuk melakukan penelitian ini. Menurut Suyanto, pelaksanaan penelitian tindakan kelas tidak menjadikan proses pembelajaran menjadi terganggu. Justru pelaksanaan penelitian harus dikerjakan sejalan dengan kegiatan sehari-hari di kelas (Subyantoro, 2020). Dengan demikian, ketika pendidik akan melaksanakan penelitian tindakan kelas, jadwal rutin yang biasa dilakukan di kelas tidak perlu dirubah.

\section{Tujuan Penelitian Tindakan Kelas}

Tujuan penelitian tindakan kelas berkaitan erat dengan keinginan pendidik untuk meningkatkan atau memperbaiki praktik pembelajaran. Penelitian ini merupakan alternatif bagi guru untuk memperbaiki permasalahan yang terjadi dalam praktik pembelajaran di kelas. Hal ini berkaitan dengan pernyataan MC. Niff yang menyatakan bahwa dasar dilaksanakannya penelitian tindakan kelas adalah untuk melakukan perbaikan. Perbaikan yang dimaksud berkaitan dengan proses pembelajaran (Sumini, 2010).

Menurut Ellys tujuan umum penelitian tindakan kelas adalah untuk menemukan solusi dan memecahkan masalah yang terjadi di kelas. Sedangkan tujuan khususnya adalah untuk mengatasi berbagai masalah yang terjadi di kelas guna memperbaiki ataupun meningkatkan kualitas proses pembelajaran (Siregar, 2014).

Selain itu, secara rinci tujuan penelitian tindakan kelas antara lain: pertama, untuk meningkatkan kualitas mutu yang berkenaan dengan proses dan hasil pembelajaran sehingga akan menghasilkan pendidikan yang berkualitas. Kedua, meningkatkan sikap profesional guru. Ketiga, membantu guru dalam mengatasi masalah pendidikan. Keempat, menumbuhkan budaya akademik di sekolah sehingga akan tercipta sikap proaktif dalam melakukan perbaikan untuk meningkatkan kualitas pendidikan (Siregar, 2014).

Penelitian tindakan kelas bertujuan untuk memperbaiki praksis pembelajaran. 
Dengan dilakukannya penelitian tindakan kelas sangat diharapkan kualitas belajar mengajar menjadi lebih baik dari sebelumnya. Penelitian tindakan kelas juga sebagai sarana untuk dapat meningkatkan kualitas program sekolah secara keseluruhan. Pada dasarnya penelitian tindakan kelas juga merupakan sebuah upaya untuk meningkatkan keterampilan guru dalam menanggulangi berbagai masalah yang muncul di kelas (Subyantoro, 2020).

Berbagai tindakan alternatif dapat dilakukan oleh guru untuk mencapai tujuan dari penelitian tindakan kelas itu sendiri. Dengan demikian, fokus penelitian tindakan kelas terletak pada tindakan yang direncanakan oleh guru, kemudian dicoba untuk diterapkan dalam pembelajaran, dan dievaluasi apakah tindakan yang dilakukan dapat menjadi solusi untuk memecahkan masalah pembelajaran yang terjadi.

\section{Manfaat Penelitian Tindakan Kelas}

Ada beberapa manfaat yang akan diperoleh dari dilaksanakannnya penelitian tindakan kelas. Secara ringkas Suyanto menyebutkan bahwa manfaat penelitian tindakan kelas antara lain mengembangkan inovasi pembelajaran, pengembangan kurikulum, dan meningkatkan profesionalitas pendidik (Subyantoro, 2020). Melalui penelitian tindakan kelas guru akan terlatih dengan sendirinya dalam mengembangkan inovasi pembelajaran dan kurikulum secara kreatif. Keterlibatan seorang guru dalam upaya pengembangan inovasi pembelajaran dan kurikulum dapat meningkatkan kinerja guru sehingga menjadi profesional.

Adapun manfaat penelitian tindakan kelas menurut Rustam dan Mundilarto diantaranya yaitu dapat meningkatkan profesionalitas guru, membantu seorang guru dalam memperbaiki mutu pembelajaran, meningkatkan rasa percaya diri seorang guru, dan melatih guru untuk aktif dalam mengembangkan pengetahuan dan keterampilannya (Siregar, 2014).

Sedangkan menurut Ani manfaat penelitian tindakan kelas diantaranya: pertama, dapat menghasilkan laporan yang dapat dijadikan sebagai rujukan atau panduan bagi para guru dalam meningkatkan ataupun memperbaiki kualitas pembelajaran. Dan hasil penelitian yang dilaporkan juga bisa digunakan sebagai bahan artikel ilmiah yang dapat dimuat di jurnal ilmiah. Kedua, menumbuhkan budaya meneliti dan menulis karya ilmiah di kalangan guru yang dapat mendukung profesionliseme guru. Ketiga, mewujudkan kerjasama dan solidaritas antar guru dalam sekolah. Keempat, meningkatkan kemampuan guru dalam menjabarkan kurikulum sesuai dengan tuntutan dan konteks lokal. Kelima, meningkatkan kemampuan pendidik dalam mengidentifikasi masalah dalam pembelajaran, dan menemukan solusi untuk memecahkan masalah yang dihadapinya. Keenam, mendorong terwujudnya pembelajaran yang menarik, menyenangkan, dan tidak monoton karena strategi maupun metode yang digunakan bervariasi (Ni'mah, 2017). Jadi, melalui penelitian tindakan kelas pendidik dapat mengembangkan praktik pembelajaran menjadi lebih optimal.

Dengan melakukan penelitian tindakan kelas pendidik akan mengetahui masalahmasalah yang ada di kelasnya dan menemukan solusi untuk mengatasi masalahmasalah tersebut. Sehingga pendidik akan 
semakin peka terhadap dinamika pembelajaran di kelasnya. Tindakan yang dilakukan pendidik dalam penelitian ini didasarkan pada masalah yang benar-benar terjadi di kelas. Dengan demikian, pendidik akan menjadi kreatif karena dituntut untuk melakukan inovasi dalam pembelajarannya untuk meningkatkan kualitas pembelajaran.

\section{Prinsip-Prinsip Penelitian Tindakan Kelas}

Ada beberapa prinsip yang perlu diperhatikan oleh peneliti (guru) dalam pelaksanaan penelitian tindakan kelas. Hopkins menyebutkan ada enam prinsip dalam penelitian tindakan kelas diantaranya; pertama, penelitian tindakan kelas yang akan dilakukan tidak boleh menggangu atau menghambat pembelajaran di kelas. Kedua, penggunaan metode pengumpulan data tidak boleh menuntut waktu yang berlebihan sehingga dapat mengganggu proses pembelajaran. Ketiga, metode yang digunakan harus dapat diandalkan sehingga pendidik dapat mengidentifikasi masalah dan merumuskan hipotesis, mengembangkan strategi yang akan diterapkan di kelasnya, dan memperoleh data yang dapat digunakan untuk menjawab hipotesis yang dikemukakannya.

Keempat, masalah yang diangkat oleh pendidik merupakan masalah pembelajaran yang nyata terjadi di kelas. Kelima, ketika melakukan penelitian pendidik harus konsisten terhadap prosedur etika yang berkaitan dengan pekerjaannya. Keenam, pendidik harus menggunakan wawasan yang lebih luas daripada perspektif kelas. Permasalahan tidak dilihat terbatas dalam konteks kelas dan/atau mata pelajaran tertentu, melainkan dalam perspektif misi dan visi sekolah secara keseluruhan (Subyantoro, 2020).

Emilia menambahkan bahwa prinsip penelitian tindakan kelas diantaranya adalah siklus yang diterapkan dalam penelitian hendaknya mengutamakan ketercapaian kriteria keberhasilan dan dikembangkan dengan perencanaan, pelaksanaan, pengamatan, dan refleksi yang terus mengalir menghasilkan siklus baru sampai penelitian tindakan kelas dihentikan. Kolaboratif penelitian tindakan kelas dapat dilakukan dengan guru, kepala sekolah ataupun pengawas sehingga mendukung kelancaran pelaksanaan tindakan kelas (Susanti, 2015).

\section{Jenis-jenis Penelitian Tindakan Kelas}

Chein, Cook, dan Harding menyebutkan ada empat jenis penelitian tindakan. Keempat jenis itu adalah penelitian tindakan diagnostik, penelitian tindakan partisipan, penelitian tindakan empiris, dan penelitian tindakan eksperimen.

Penelitian tindakan diagnostik ialah penelitian yang dirancang untuk menuntun ke arah tindakan. Peneliti memasuki situasi yang telah ada dan mendiagnosis situasinya. Setelah melakukan diagnosis, kemudian peneliti membuat rekomendai terkait tindakan perbaikannya. Akan tetapi rekomendasi yang dibuat tidak diuji sebelumnya. Rekomendasi yang dihasilkan melalui proses intuitif berdasarkan pengalaman masa lalu dan diagnosis saat itu. Karena rekomendasi dibuat oleh peneliti yang tidak terlibat dalam kehidupan tersebut, ada kemungkinan rekomendasi tersebut tidak realistik, 
Penelitian tindakan partisipan ialah apabila orang yang melakukan penelitian harus terlibat langsung dalam proses penelitian dari awal hingga menghasilkan laporan penelitian. Peneliti senantiasa terlibat sejak perencanaan penelitian, kemudian memantau, mencatat, dan mengumpulkan data, lalu menganalisa data hingga berakhir dengan melaporkan hasil penelitiannya. Dalam penelitian ini orang yang akan melakukan tindakan harus terlibat dalam proses penelitian. Dengan demikian, peneliti tidak hanya menyadari perlunya melakukan program tindakan tertentu, tetapi juga akan terlibat di dalamnya.

Penelitian tindakan empiris adalah apabila peneliti berupaya melakukan suatu tindakan dan membukukan apa yang dilakukan dan yang terjadi selama tindakan berlangsung. Proses penelitian berkaitan dengan penyimpanan catatan dan pengumpulan pengalaman peneliti dalam pekerjaan sehari-hari. Jadi, inti dari penelitian tindakan empiris ini adalah melakukan suatu tindakan dan membukukan apa yang dilakukan dan yang terjadi.

Penelitian tindakan eksperimental ialah apabila dilakukan upaya menerapkan berbagai strategi secara efektif dalam kegiatan pembelajaran. Dengan diterapkannya penelitian ini diharapkan peneliti dapat menetukan strategi yang paling efektif dan efisien dalam mencapai tujuan pembelajaran.

Dibandingkan dengan jenis penelitian tindakan lainnya, penelitian tindakan eskperimental ini memiliki nilai potensial terbesar dari semua jenis penelitian tindakan untuk kemajuan pengetahuan ilmiah karena dalam keadaan yang menguntungkan memberikan uji-coba yang mantap tentang hipotesis tertentu. Akan tetapi, penelitian ini juga merupakan penelitian tindakan yang tersulit untuk dilakukan dengan berhasil.

Kesulitan-kesulitan yang mungkin akan timbul dalam penelitian ini diantaranya; keterbatasan kemampuan peneliti dalam membuat prediksi keakuratannya, kurang mampunya peneliti dalam mengontrol jalannya tindakan sosial, dan kurang mampunya peneliti dalam melakukan pengukuran yang layak sesuai dengan sifat dasar hubungan sosial. Kesulitan-kesulitan tersebut dapat dihindari apabila dari awal penelitiannya telah direncanakan program untuk bekerja sama dengan peneliti yang bertanggung jawab atas pemantauan pelaksanaan kegiatan penelitian.

\section{Prosedur Penelitian Tindakan Kelas}

Peneliti (guru) yang akan melakukan penelitian tindakan kelas harus mengikuti prosedur tertentu agar kegiatan penelitian dapat dilakukan secara sistematik. Fokus kegiatan dalam pelaksanaan penelitian tindakan kelas antara lain; planning (perencanaan), acting (tindakan), observing (pengamatan), dan reflecting (refleksi) (Susilowati, 2018). Kegiatan-kegiatan tersebut merupakan satu siklus kegiatan pemecahan masalah. Apabila satu siklus telah dilaksanakan dan belum menunjukkan adanya perbaikan atau peningkatan mutu, maka dilanjutkan pada siklus kedua, begitu seterusnya hingga masalah yang diteliti dapat dipecahkan. Berikut penjelasan langkahlangkah penelitian tindakan kelas.

Planning (perencanaan), ada beberapa kegiatan yang dilakukan pada tahap planning ini diantaranya identifikasi masalah, 
perumusan masalah, analisis penyebab masalah dan pengembangan intervensi (action). Setelah mengidentifikasi masalah, barulah peneliti dapat melakukan perencanaan untuk menentukan langkahlangkah yang akan dilakukan oleh peneliti untuk memecahkan masalah yang dihadapi.

Acting (tindakan), tindakan tersebut dilakukan oleh peneliti (guru) untuk memperbaiki masalah yang dihadapi. Tindakan yang dimaksud diartikan sebagai perbuatan yang dilakukan sebagai upaya peningakatan, perbaikan, dan perubahan sebagai sebuah solusi. Tindakan yang dilakukan harus mengacu pada rencana pembelajaran yang telah ditetapkan.

Observing (pengamatan), pengamatan yang dimaksud adalah kegiatan pengambilan data saat penelitian atau kegiatan pengamatan untuk melihat sejauh mana efek dari tindakan yang dilakukan telah mencapai sasaran. Pengamatan ini harus menghasilkan laporan sebagaimana apa yang telah terjadi dalam proses belajar mengajar. Penggunaan alat pengambil data yang beragam memungkinkan peneliti dapat menangkap secara detail informasi yang diperlukan untuk membuat laporan. Data kuantitaif tentang kemajuan siswa yang berupa nilai dan data kualitatif tentang minat atau suasana kelas perlu dikumpulkan. Pada tahap ini peneliti menguraikan jenis data yang dikumpulkan, metode pengumpulan data, dan alat koleksi data.

Reflecting (refleksi), refleksi yang dimaksud adalah suatu kegiatan mengulas secara kritis tentang perbaikan yang terjadi pada siswa, guru, dan suasana kelas. Pada tahap refleksi ini, seorang guru yang berperan sebagai peneliti menjawab pertanyaan mengapa, bagaimana, dan sejauh mana intervensi atau tindakan telah menghasilkan perubahan. Apabila pada suatu siklus peneliti belum merasa puas, maka peneliti (pendidik) dapat menyempurnakan intervensi atau tindakan sehingga pada pelaksanaan siklus berikutnya dapat dilakukan perubahanperubahan ke arah yang lebih baik dan dapat menghasilkan pembelajaran yang berkualitas.

Alur sebuah penelitian pada akhirnya akan bermuara pada pembuatan laporan penelitian. Laporan penelitian tindakan kelas ditulis setelah penelitian selesai dilaksanakan sesuai dengan format yang ditentukan oleh lembaga terkait. Adapun hal yang perlu ditulis pada laporan penelitian tindakan kelas setidaknya memuat beberapa aspek yang berkaitan dengan; kondisi kelas tempat dilaksanakannya penelitian tindakan kelas, disertai dengan penjelasan adanya perbedaan antara model pembelajaran yang biasa dilakukan di kelas dengan model pembelajaran yang sedang dilaksanakan melalui penelitian tindakan kelas. Penjelasan hasil pelaksanaan dari tiap siklus yang dilengkapi dengan data hasil pengamatan dan hasil refleksinya. Setelah semua siklus dijelaskan, selanjutnya adalah hasil analisis peneliti (pendidik) dengan memperhatikan hasil keseluruhan siklus.

Karya ilmiah yang telah dibuat bisa dipublikasikan melalui penerbitan ataupun presentasi lisan. Apabila pendidik ingin mempublikasikan karya ilmiah yang telah dibuat melalui penerbitan, maka pendidik bisa mengirimkan karyanya ke media penerbit seperti jurnal pendidikan atau pembelajaran. Dan tentunya pendidik harus memperhatikan persyaratan teknis yang telah 
ditetapkan oleh media penerbit tersebut. Namun apabila pendidik ingin mempublikasikannya melalui presentasi lisan, maka pendidik bisa mempresentasikannya melalui seminar, diskusi dan sebagainya. Pemasalahannya, sebagian besar pendidik sangat jarang sekali berkesempatan untuk mempresentasikan karya ilmiah dengan cara seperti ini. Mungkin saja hal ini disebabkan karena kesibukan masing-masing pendidik. Kebanyakan pendidik hanya berperan sebagai pendengar saja bukan sebagai pembicara. Agar hal tersebut bisa terwujud, pendidik bisa bekerja sama dengan teman sejawat dalam Musyawarah Guru Bidang Studi (MGBS) untuk merencanakanan dan mengadakan seminar dengan pembicara dari mereka (pendidik) sendiri secara bergiliran tanpa mengundang orang dari luar. Dengan demikian, pendidik bisa berkesempatan untuk mempresentasikan karya ilmiah yang telah dibuat melalui presentasi lisan atau seminar.

Tujuan dari publikasi karya ilmiah pendidik adalah agar pendidik dapat mengembangkan ilmu pengetahuan, teknologi dan seni serta memiliki kepribadian yang kuat sesuai dengan profesinya. Publikasi karya ilmiah juga bermanfaat bagi sekolah agar mampu menjadi organisasi pembelajaran yang efektif, sehingga dapat meningkatkan kompetensi, dedikasi dan komitmen pedidik dalam memberikan layanan pendidikan yang berkualitas (Subyantoro, 2020). Selain itu, publikasi karya ilmiah juga bermanfaat bagi pembaca yang ingin melakukan penelitian tindakan kelas untuk menambah pengetahuan.

\section{KESIMPULAN}

Penelitian tindakan kelas adalah penelitian tindakan yang dilakukan oleh guru secara sistematis reflektif untuk memperbaiki praktik pembelajaran dan meningkatkan kinerja guru sehingga menjadi guru yang profesional. Melalui penelitian tindakan ini maka kualitas pendidikan di sekolah akan meningkat secara berkelanjutan dan menjadi lebih baik dari sebelumnya. Adanya tindakan-tindakan tertentu yang dilakukan oleh peneliti (guru) untuk memperbaiki permasalahan pembelajaran menjadi karakteristik khas dari penelitian tindakan kelas.

Penelitian tindakan kelas merupakan bagian terpenting dari upaya pengembangan profesi guru. Dengan demikian, guru akan terlatih dengan sendirinya untuk berpikir kritis dalam memecahkan permasalahan yang dialaminya dalam proses pembelajaran. Oleh karena itu, penelitian tindakan kelas sangat perlu dilakukan oleh guru untuk memperbaiki atau meningkatkan kualitas pembelajaran dan pengembangan diri menjadi guru yang profesional.

\section{DAFTAR PUSTAKA}

Ni'mah, Zetty Azizah. (2017). Urgensi Penelitian Tindakan Kelas Bagi Peningkatan Profesionalisme Guru Antara Cita Dan Fakta. Jurnal Realita Vol 15,(2): 1-22.

Siregar, Ellys. (2014). Pengembangan Profesionalisme Guru Melalui Penelitian Tindakan Kelas. Jurnal Pengabdian Kepada Masyarakat 20,(77): 173-186. 
Subyantoro. (2020). Penelitian Tindakan Kelas (Metode, Kaidah Penulisan, Dan Publikasi). Depok: Rajawali Press.

Sumini, Th. (2010). Penelitian Tindakan Kelas Dan Pengembangan Profesi Guru. Jurnal Historia Vitae Vol 24,(1).

Susanti, Emilia., dan Dicki Hartanto. (2015). Peningkatan Kompetensi Guru Melalui Penerapan Penelitian Tindakan Kelas (PTK) Dalam Pendidikan Islam. Jurnal Potensia Vol 14,(1): 151-174.

Susilowati, Dwi. (2018). Penelitian Tindakan Kelas (PTK) Solusi Alternatif Problematika Pembelajaran. Jurnal Ilmiah Edunomika Vol 2,(3): 36-46. 